\title{
The mapping of forested archaeological sites using UAV LiDaR. A feedback from a south-west France experiment in settlement \& landscape archaeology.
}

\section{La cartographie des sites archéologiques forestiers au moyen d'un}

\section{LiDaR embarqué par drone. Un retour d'expérience du Sud-Ouest de la} France en archéologie du paysage et du peuplement.

\author{
Nicolas Poirier ${ }^{1}$, François Baleux ${ }^{2}$, Carine Calastrenc ${ }^{3}$ \\ ${ }^{1}$ CNRS UMR 5608 TRACES, Université Toulouse - Jean-Jaurès, France, nicolas.poirier1@univ-tlse2.fr \\ ${ }^{2}$ CNRS UMR 5608 TRACES, Université Toulouse - Jean-Jaurès, France, francois.baleux@univ-tlse2.fr \\ ${ }^{3}$ CNRS UMR 5608 TRACES, Université Toulouse - Jean-Jaurès, France, carine.calastrenc@univ-tlse2.fr
}

\begin{abstract}
The recent democratisation of UAVs and the progress made in sensor miniaturisation now make it possible to embark miniaturised LiDaRs on board mini-UAVs. This possibility opens the way to a more systematic use of Lidar technology for the survey of small forested areas and for the mapping of isolated archaeological sites. The paper presents a feedback from the Garonne valley where the acquisition of Lidar data by drone on three archaeological forested sites allows to discuss the variations in the extent and use of the current forested area. The quality of UAV-Lidar data is also compared to data acquired by plane.

RÉSUMÉ. La démocratisation récente des drones et les progrès réalisés en matière de miniaturisation des capteurs permettent aujourd'hui d'embarquer des LiDaR miniaturisés à bord de mini-drones. Cette possibilité ouvre la voie à un recours plus systématique à la technologie Lidar pour la prospection de petits massifs forestiers et pour la cartographie de sites archéologiques isolés. L'article présente un retour d'expérience réalisé dans la vallée de la Garonne où l'acquisition de données Lidar par drone sur trois sites archéologiques forestiers permet de discuter les variations d'emprise et d'usage de la forêt actuelle. La qualité des données Lidar acquises par drone est également comparée à des données acquises par avion.

KEYWORDS. Drone, LiDaR, cartographie 3D, archéologie du paysage, dynamiques de peuplement.

MOTS-CLÉS. UAV, LiDaR, 3D mapping, landscape archaeology, settlement dynamics.
\end{abstract}

\section{Introduction}

\subsection{Forests as archaeological repositories}

Forests have a history too. Long regarded as the uncultivated margins of the lands exploited by rural communities, they have been thought to be present since immemorial time, little frequented and feared for the dangers - real or supposed - that they contain.

Although it is now accepted that human interventions since the Neolithic period have led to the fragmentation and sharp reduction of forested areas (Rackham 1980; Roberts et al. 2018), recent works tend to demonstrate the essential economic role of these areas, in particular through the development of the wood resource, building material and fuel essential to the development of craft activities such as coal mining, metallurgy, lime production (Dupin et al. 2017; Py-Saragagaglia et al. 2017; Rassat et al. 2013; Szabó et al. 2015).

Other works have shown the moving nature of forested areas, as far as the topographical imprecision of ancient archival sources allow to estimate it. Indeed, it appears that these wooded areas may have served as a "decompression valve" for over-exploited soils and subjected to major population growth episodes requiring the cultivation of new areas, either permanently or temporarily (Viader and Rendu 2014). 
Today's forested areas are therefore recognised as conserving archaeological remains that bear witness to activities that took place before or during the development of the forest cover (Rotherham 2007). In contrast to cultivated areas, sometimes intensely reworked, using mechanised machines that disturb the subsoil to depths of up to one meter, today's forested areas have "fossilised" the imprint of past activities in various forms: traffic routes, flattened masonry, mounds, platforms, or simple micro-reliefs that are almost invisible to the naked eye. Indeed, human interventions in forest management are less numerous and less invasive in the subsoil, and the regular supply of humus by falling leaves provides a protective carpet for the flattened structures and micro-reliefs.

The archaeological approach of these traces allows us to anchor the history of current forested areas in the long-time duration of rural areas' construction by ancient societies. It makes it possible to measure the spatial dynamics that may have affected the location and influence of these wooded areas over time. Thus, any of them considered to be very old, established for a long time on the periphery of main cultivated areas, may appear to be moving and of fairly recent genesis, having preserved the traces of very different previous landscapes: open landscapes, built-up areas, cultivated or pastured areas, defended areas.

\subsection{LiDaR as a tool to investigate past activities in current forested areas}

For about 30 years now, LiDaR technology has been essential for documenting both the health status of forests (Nelson 1989) and the archaeological potential they contain (Devereux et al. 2005). Sending a high-density laser beam from an airborne platform towards the ground allows a complete scanning of the landscape generating very large point clouds (Wehr and Lohr 1999). The classification of the recorded echoes (high, medium and low vegetation, buildings, ground) allows the extraction of a Digital Terrain Model (DTM) after filtering the ground points and virtual suppression of the vegetation. This step is sensitive to the state of the vegetation, the density of the undergrowth and the topographical characteristics of the areas overflown and requires archaeological expertise to determine the best compromise between filtering the low vegetation and conserving the archaeological micro-reliefs (Humme, Lindenbergh and Sueur 2006; Meng, Currit and Zhao 2010; Zhang et al. 2016).

This Digital Terrain Model, which represents the bare ground, can be the object of different visualization techniques allowing to highlight the most discrete micro-reliefs (whether positive or negative). The most well-known are the mono- or multi-directional shading techniques allowing to simulate the emission of a light source from a height and a direction set by the operator. But many other techniques exist to highlight micro-reliefs of archaeological interest: openness, slope intensity, skyview factor, etc. (Bennett et al. 2012; Kokalj and Somrak 2019; Kokalj, Zaksek and Ostir 2011; Štular et al. 2012).

This technique has been used to document large forested areas and thus reveal their archaeological potential (Bewley, Crutchley and Shell 2005; Challis et al. 2008; Georges-Leroy et al. 2011; Sittler 2004). Where field work such as ground surveys have only been able to document relatively small areas, and with low topographic accuracy due to the difficulties related to the forested environment (Doyen, Decocq and Thuillier 2004; Glaves et al. 2009), LiDaR data provide a form of spatial continuity of information that is conducive to the identification of spatial patterns over large areas, such as land plots, roads, mining or coal mining areas (Georges-Leroy et al. 2010).

\subsection{Democratization of UAVs and miniaturizing of sensors}

Over the last ten years or so, UAVs have become powerful allies in archaeological research, firstly by making available to as many people as possible this "bird's-eye view" that was until now reserved for those familiar with aerial survey (Campana 2017). 
Indeed, the progress made in pilot assistance today allows any user to operate these flying machines after limited theoretical and practical training, without necessarily being an experienced pilot, thanks to the implementation of inertial stabilization and autopilots, as well as the use of highprecision GPS positioning.

In the same way, the progress made in terms of miniaturisation of on-board sensors now makes it possible not only to combine a high-resolution digital camera with a mini-UAV (Hendrickx et al. 2011), but also multispectral (Agudo et al. 2018), thermal (Poirier, Hautefeuille and Calastrenc 2013), magnetic or laser sensors (Risbøl and Gustavsen 2018).

\section{Study area and problematics}

\subsection{REPERAGE project}

The study area is located in the South-West of France, about $50 \mathrm{~km}$ north of Toulouse. It concerns the interfluvial plateau that separates the courses of the Garonne and the Tarn rivers (Figure 1).

The REPERAGE project aims to study the processes of human settlement of the river valley and the lower terraces of the Garonne, through the use of, among other methods, systematic fieldwalking surveys. It aims at developing a comprehensive, non-invasive archaeological strategy which combines high resolution mapping of fieldwalking artefacts, low altitude aerial surveys using unmanned aerial vehicles on-board multispectral and LiDaR sensors, geophysical surveys (GPR, magnetometer) and the study of medieval \& modern written documentation. The objective is to obtain a high level of non-invasive knowledge on diachronic settlement systems and dynamics, as on relationships between past human societies and the natural environment (Poirier 2017).

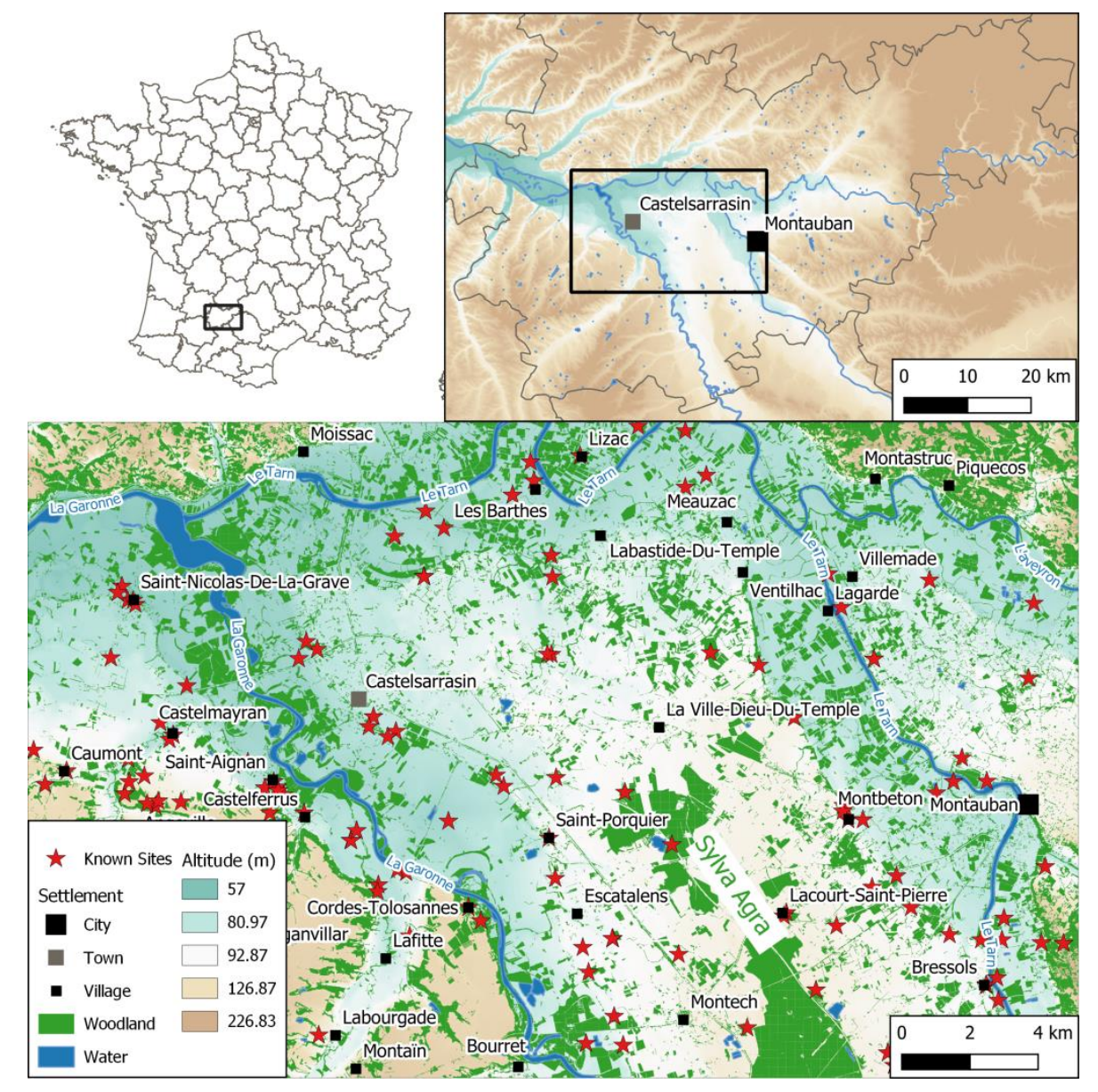

Figure 1. Location of the Study Area 


\subsection{Holes in the map: forested areas}

This ambition, as is often the case in micro-regional studies, is limited by biases induced by survey methods, which inevitably leave gaps in the archaeological coverage of the information. For example, currently inhabited areas (towns and villages, hamlets and isolated settlements) are by definition inaccessible to non-invasive methods. These areas can therefore cover a certain amount of information essential to the understanding of land-use dynamics.

This is also the case for areas that are now forested. Their archaeological potential is hardly revealed with pedestrian survey techniques, which must necessarily be adapted to the particular conditions of the forest: complexity to maintain an alignment and regular spacing between surveyors, difficulty in detecting artefacts on the surface of a soil covered with humus and leaves, etc.

As a result, current forest areas often constitute "holes" in micro-regional archaeological maps. Only a few particularly well-preserved sites, long explored by local scholars, may be mentioned in the ancient bibliography.

This is the case of the main forest area that concerns our study zone. Indeed, the distribution of known archaeological sites, recorded in the National Archaeological Map, are mainly concentrated in the plain areas and on the edges of plateaus, leaving empty the interfluvial space between the Tarn and the Garonne, which is supposed to be largely occupied by wooded areas in the past (Figure $1)$.

These forested areas, now fragmented, are reputed to be the remains of a single large woodland, the sylva agra, supposed to have been present from immemorial time in the location of soils unfavourable to agriculture (Delsouc 2001). This forest is mentioned in written sources as early as the $8^{\text {th }}$ century as the property of the neighbouring abbey of Moissac (Noël 1996), although its extent is not exactly known. The population growth of the $12^{\text {th }}-13^{\text {th }}$ centuries, proven by the expansion of cultivated land and the foundation of new villages (Higounet 1975), is supposed to have contributed to the fragmentation of this woodland area (Deffontaines 2000; Gilles 1966). The forest of Agre received royal status in 1361 (Langevin 1970), although part of its area remained the property of the abbey of Moissac until the $18^{\text {th }}$ century (Gilles 1966: 366). It became a "state forest" during the French Revolution.

Four archaeological sites are recorded within the extent of the present Agre forest. LiDaR overflights have been conducted on three of them in order to clarify their morphology and microtopography and to get an overview of their surroundings. The last site, discovered during motorway works, is now destroyed. It was a Gallo-Roman potter's kiln or tile kiln.

\subsection{Problematics}

It emerges from these preliminary observations that the history of the forest is probably not linear, starting from a large "immemorial" woodland covering most of the ungrateful plateau of the Tarn-Garonne interfluve, regularly attacked and cleared by ancient societies according to their population growth and the need for arable land, then "fossilised" by the royal or state authorities in order to guarantee the sustainability of the wood resource.

On the contrary, the presence in the heart of today's forest of sites from ancient and medieval times a priori unrelated to logging (grave sites, ovens, church and mound) testifies to a more complex history of these wooded areas, made up of phases of growth and decay, spatial and chronological pulsations of the forested area. 
These forested sites have generally been known for a long time, but the context of their location, the difficulties of access and transport of topographical equipment have led to a very partial, incomplete and imprecise state of knowledge of their morphology and micro-topography, so that only the site known as the "Roman camp" had been the subject of a sketch describing the layout of the structures. For the others, no map had ever been made of them. We can thus measure the considerable contribution of LiDaR technology embarked by drone to access quality information concerning isolated sites in the forest, of small surface area and presenting modest structures.

\section{Equipment and methodology}

\subsection{UAV: platform \& field logistics}

We use a commercial DJI MATRIX 600 PRO UAV (Figure 2). This $9 \mathrm{~kg}$ drone is equipped with 6 intelligent LiPo $6 \mathrm{~S} 4500 \mathrm{mAh}$ batteries. It can carry up to $6 \mathrm{~kg}$. It is equipped with a dust-resistant propulsion system and self-cooling motors that ensure very good reliability for long duration acquisitions. Its two D-RTK GNSS antennas receive the GPS L1/L2 and GLONASS F1/F2 constellations, which are resistant to strong magnetic interference and allow centimetre-level positioning. Its retractable landing gear allows vertical measurements to be taken without any shadow zone. Flight programming is based on the DJI Go application.

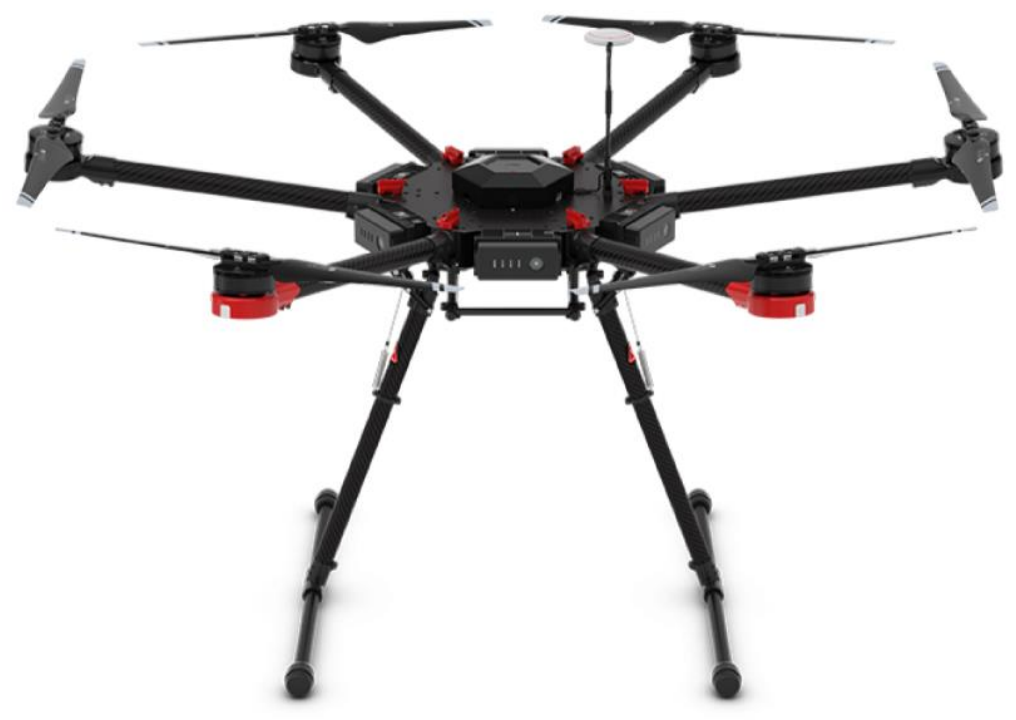

Figure 2. DJI Matrix 600 Pro Drone

The flight plan is based on waypoints that determine the equidistant flight lines followed by the UAV. The distance between each flight line is $25 \mathrm{~m}$ which allows an overlap of at least $50 \%$. Acquisitions are carried out at an average height of $50 \mathrm{~m}$ from the ground, and a constant speed of 4 $\mathrm{m} / \mathrm{s}$.

\subsection{A miniaturized LiDaR: Yellowscan sensor \& data processing}

We use the LiDaR Mapper II sensor designed by the Yellowscan company which is specifically dedicated to UAV acquisitions (Figure 3). It allows us to take points with an accuracy of $10 \mathrm{~cm}$ in $\mathrm{X}$ and $\mathrm{Y}$ and $5 \mathrm{~cm}$ in $\mathrm{Z}$. 
Its weight of $2.1 \mathrm{~kg}$ allows implementation on many UAV supports. Its autonomy (1.5 hours) and the fast generation of .las files are its main assets.

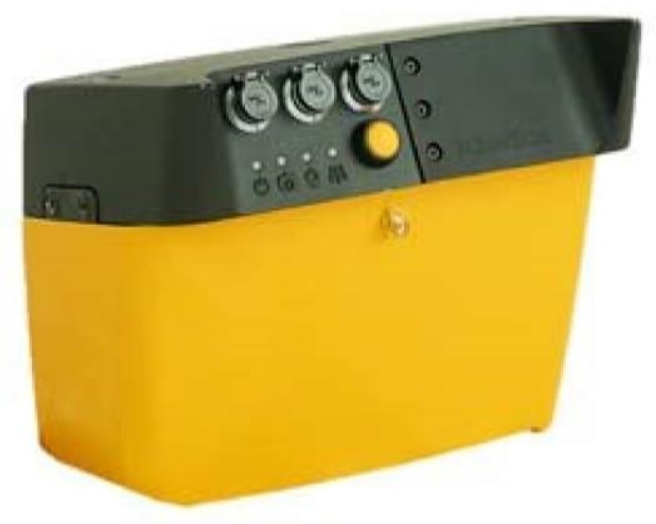

Figure 3. Yellowscan LiDaR Mapper II

Within the framework of the flight parameters retained by the team $(50 \mathrm{~m}$ height, $4 \mathrm{~m} / \mathrm{s})$, it is possible to expect a density of points around $30 \mathrm{pts} / \mathrm{m}^{2}$ at emission (Figure 4). The density of the ground points depends on the state of the vegetation cover.

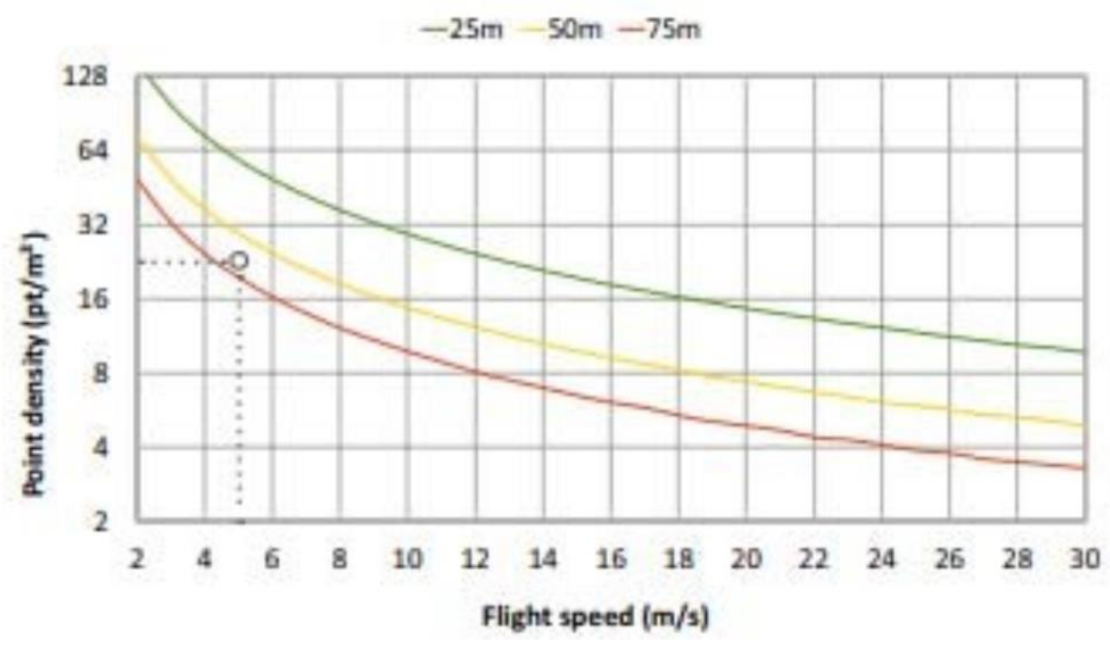

Figure 4. Density of emitted points according to height and acquisition speed (manufacturer's data)

The post-processing of data is generally carried out using PosPac, QSGis and CloudCompare softwares.

Pospac is a software published by Applanix $^{1}$ dedicated to inertial post-processing of georeferenced data. It allows to reach a data positioning accuracy at the centimetre level without the support of a base station on the acquisition field itself, but by mobilizing the stations of the Permanent Geodetic Network of the French National Geographic Institute ${ }^{2}$ for terrains located in France.

Qgis $^{3}$ is a free Geographic Information System software. The Yellowscan company, designer of the miniaturized LiDaR has developed an extension of this platform dedicated to the pre-processing of data: inertial correction, assembly of flight lines, construction of the point cloud.

\footnotetext{
1 ttps://www.applanix.com/

${ }^{2}$ ttp://rgp.ign.fr/RESEAU/presentation.php 
CloudCompare ${ }^{4}$ is a free $3 \mathrm{D}$ processing software. It allows the navigation in the point cloud, the extraction of ground points thanks to its CSF module (Zhang et al. 2016) and the construction of the Digital Terrain Model.

\subsection{DTM visualization techniques \& interpretation}

After extraction of the ground points and generation of the Digital Terrain Model, an important step of the analysis consists in the realization of adapted visualizations of the produced DTMs. This step is generally performed using the open source software Relief Visualization Toolbox ${ }^{5}$ (RVT). Below is a short description of each visualization method from the online manual of the RVT application $^{6}$ :

- Analytical hillshading is straightforward to interpret even by non-experts and without training. However direct illumination restricts the visualization in dark shades and brightly lit areas, where no or very little detail can be perceived. A single light beam also fails to reveal linear structures that lie parallel to it which can be problematic in some applications, especially in archaeology.

- Analytical hillshading can be calculated in multiple directions. The 8-bit image is a result of calculation in three directions, separated by $60^{\circ}$

- Principal Components Analysis (PCA) is a mathematical procedure that summarizes the information of correlated data; hillshaded images from multiple directions in this case.

- Slope gradient represents the maximum rate of change between each cell and its neighbours.

- Local relief modelling removes the large-scale morphological elements (hills, valleys...) from data so only small-scale features remain (Hesse 2010)

- Sky-view factor is a proxy for diffuse illumination and measures the proportion of the sky visible from a given point. Locally flat terrain, ridges and earthworks (e.g. building walls, cultivation ridges, burial mounds) which receive more illumination are highlighted and appear in light to white colours on a SVF image, while depressions (e.g. trenches, moats, ploughing furrows, mining pits) are dark because they receive less illumination (Zakšek, Oštir and Kokalj 2011).

- Anisotropic sky-view factor assumes that the sky is brighter in some directions than in others.

- Openness is also a proxy for diffuse illumination and is based on an estimation of a mean horizon elevation angle within a defined search radius. The mean value of all zenith angles gives positive openness, while the mean nadir value gives negative openness. Positive openness is similar to sky-view factor, with a more 'flattened feel', while negative openness gives additional information on convex features. Because it is direction and shading independent and removes general topography, it is useful for automatic feature recognition.

- Visualization for archaeological topography (VAT) combines hillshading (or hillshading from three directions), slope, positive openness and sky-view factor with predetermined calculation and blending settings for 'normal' (complex) and very flat terrain.

\footnotetext{
${ }^{4}$ ttps://www.danielgm.net/cc/

${ }^{5}$ https://iaps.zrc-sazu.si/en/rvt\#v, (Kokalj and Somrak 2019; Zakšek, Oštir and Kokalj 2011)

${ }^{6}$ https://iaps.zrc-sazu.si/sites/default/files/rvt_2.2.1_0.pdf
} 
A second step under QGIS concerns the vectorization of the detected anomalies. By superimposing the different visualizations of the DTM, the archaeological map of the anomalies is progressively completed by taking advantage of each visualization.

A final analytical step is to produce plans and sections of the identified anomalies in order to evaluate their importance in terms of microtopography and to characterize the identified structures more precisely.

\section{Results: mapping of three forested archaeological sites}

\subsection{The "roman camp"? a trapezoidal enclosure}

Located in the commune of Saint-Porquier, the first site is known as the "Roman camp" and was described as early as 1852 as "a trapezium, whose four faces correspond fairly exactly to the four cardinal points [...] The enclosure, which is currently planted with oaks and obstructed by scrub, contains 5,880 square meters [...]".7

A rough sketch is then proposed (Figure 5), mentioning gates and the presumed location of the Praetorian tent (!).

As far as we know, no other field investigation has been carried out on this site, so no more precise plans or more reliable clues regarding its dating were available.

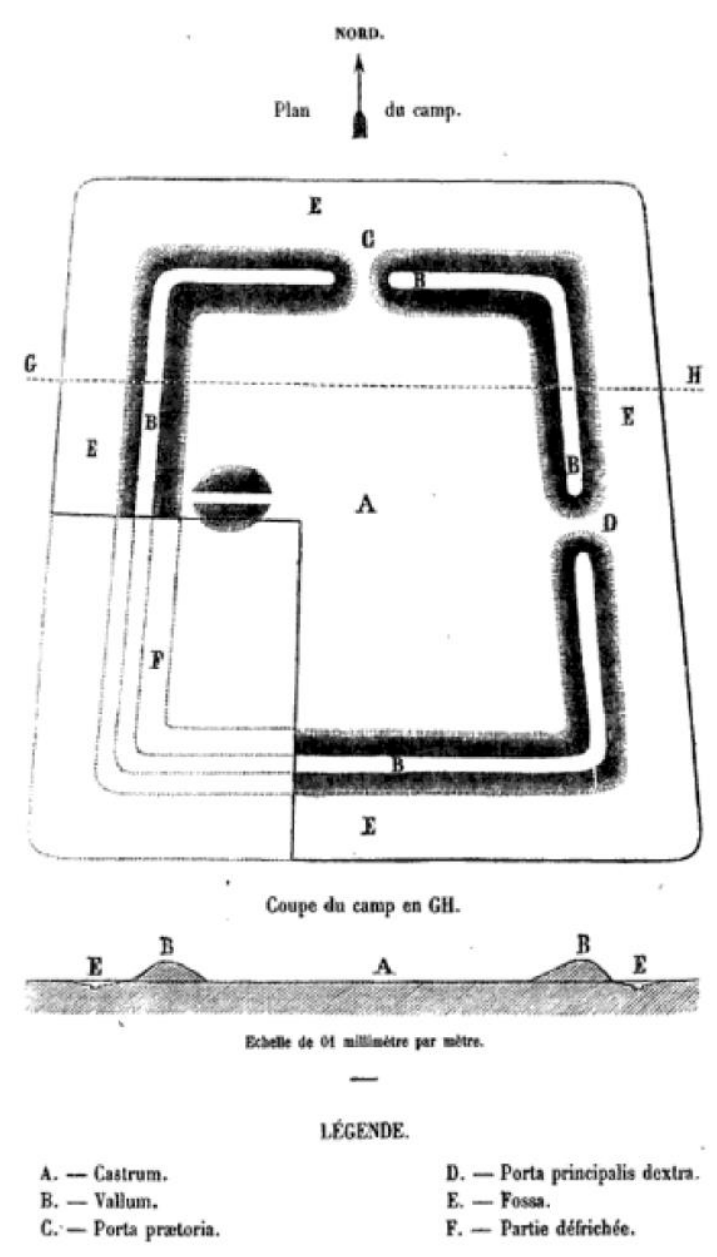

Figure 5. Schematic plan of the site proposed in 1852

\footnotetext{
${ }^{7}$ Mémoire de la Société Archéologique du Midi de la France, Volume 7, p.314-319.
} 
Thanks to the LiDaR overflight of the area, this site, which had never been the subject of precise topographical surveys, was revisited. Ten minutes of flight allowed the acquisition of several hundreds of thousands topographic points, especially on the ground, allowing the production of a fine Digital Terrain Model (Figure 6) and different visualizations derived (Figure 7).

The digital site model makes it easy to measure the length, width and depth of ditches, enclosure surface and slope height. We can therefore recognize a quadrangular, slightly trapezoidal ditched and embankment structure, $65 \mathrm{~m}$ long on the short sides and $85 \mathrm{~m}$ long on the long sides, delimiting an enclosed area of $4900 \mathrm{~m}^{2}$.

The part indicated as "cleared" in 1852 has now been returned to the forest, but it can be seen that the agricultural work carried out following this clearing has completely flattened the ditched structure and its embankment (Figure 8).

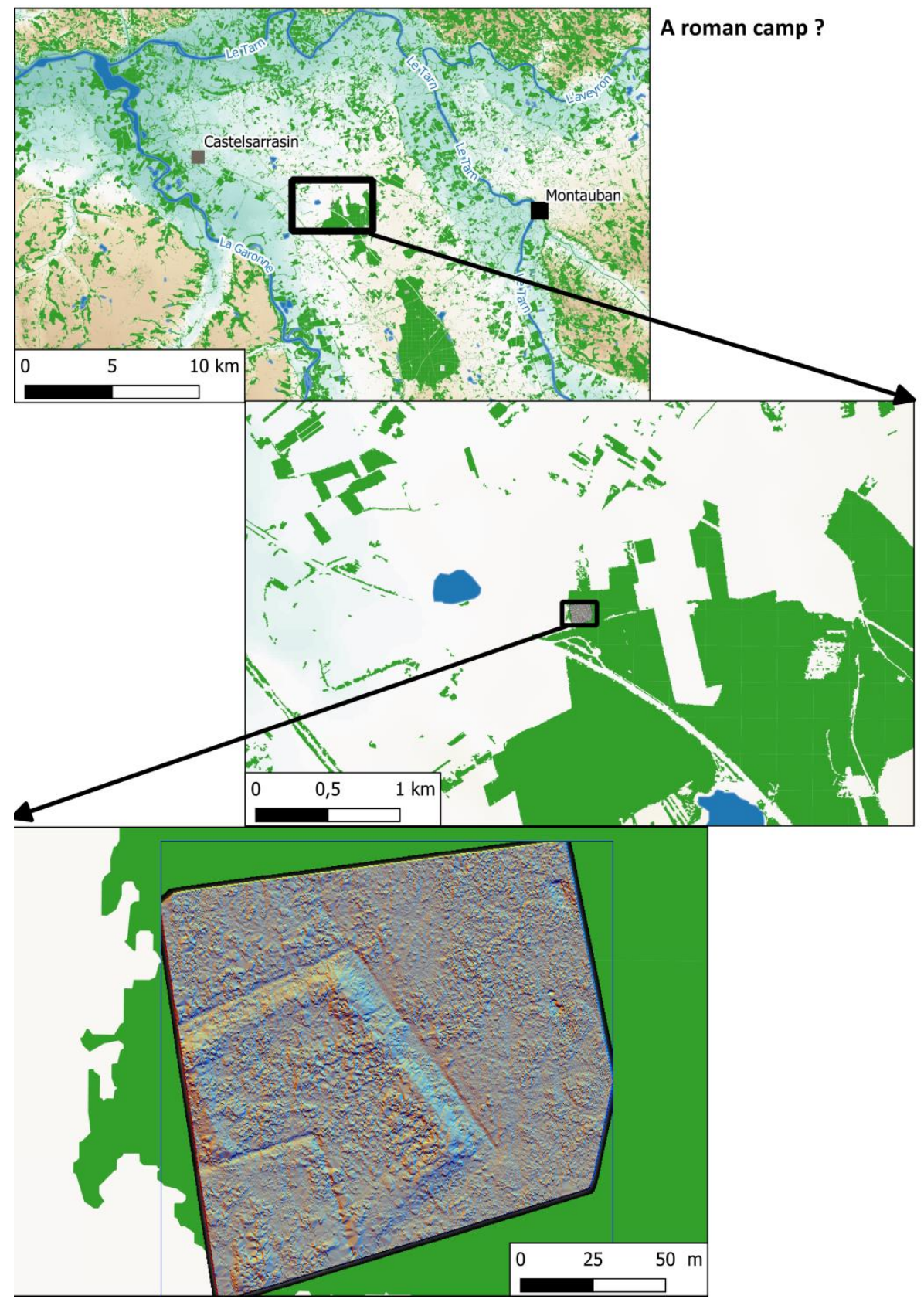

Figure 6. LiDaR survey of "Roman Camp" structures (Hillshading - azimuth $315^{\circ}$, angle 45) 


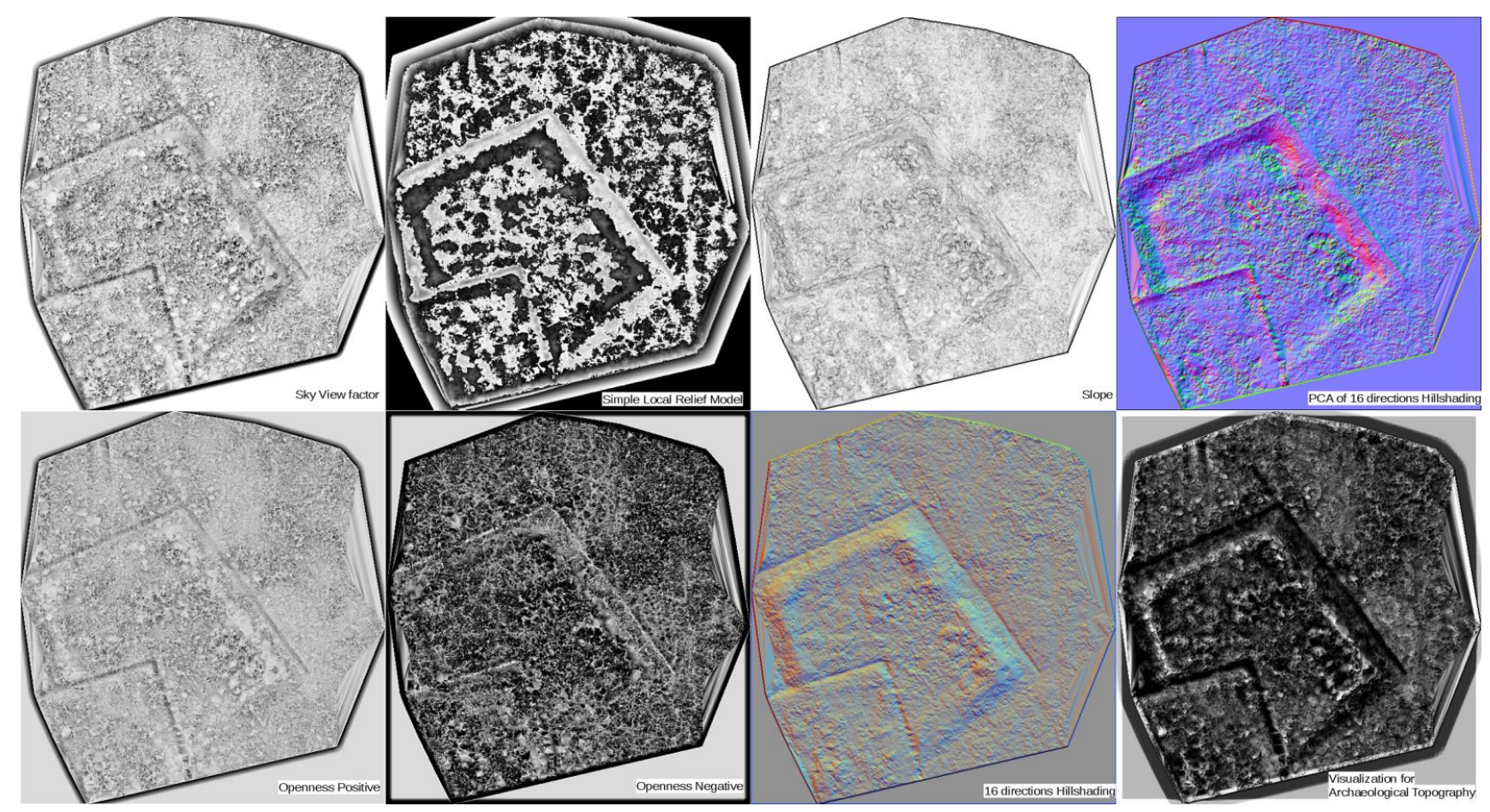

Figure 7. Different visualizations of the DTM at the "Roman camp" site (RVT software)

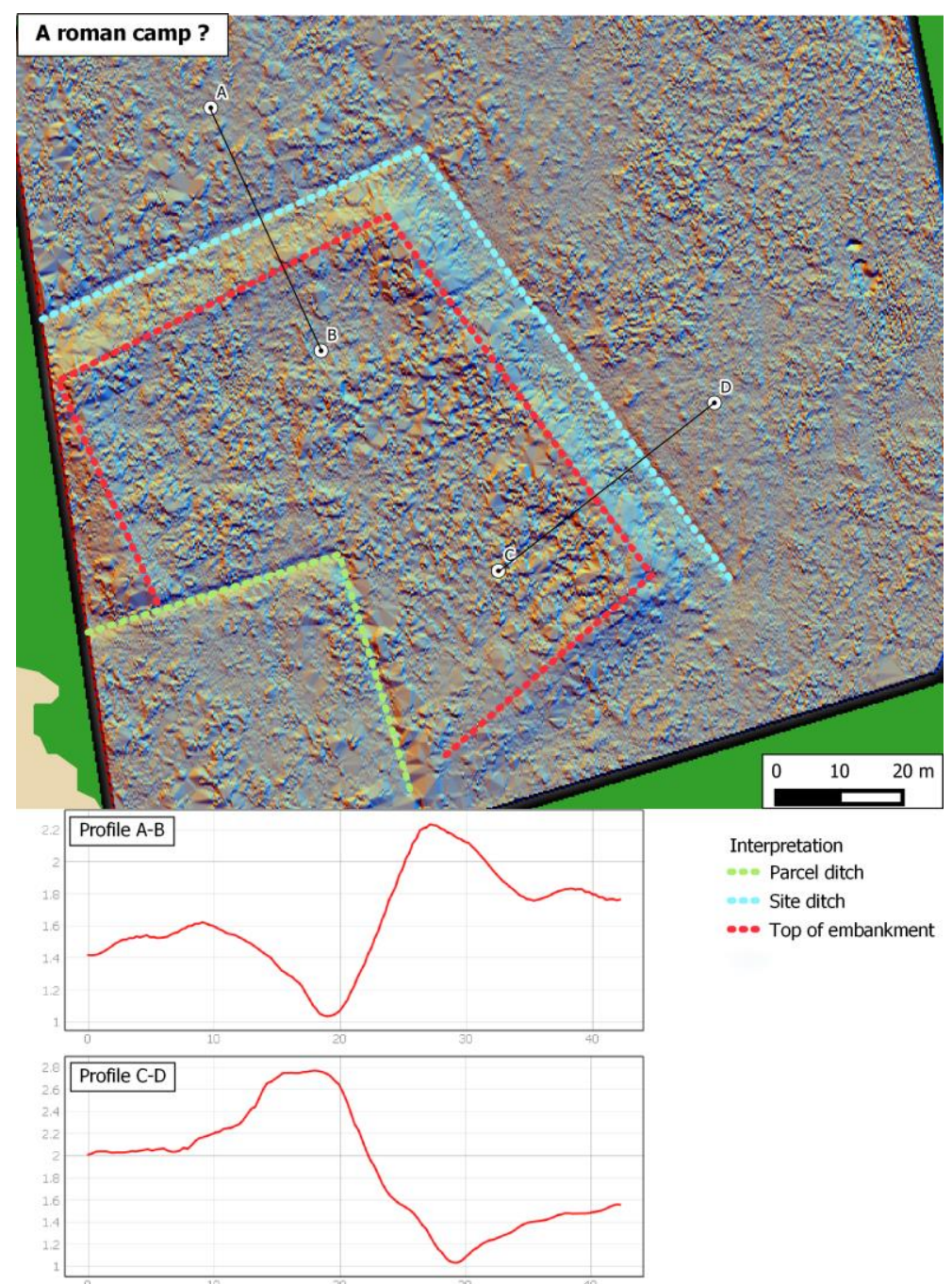

Figure 8. Different visualizations of the DTM at the "Roman camp" site (RVT software) 
Since the density of the undergrowth did not allow us to prospect this site on the ground, we cannot confirm the supposed roman dating in the $19^{\text {th }}$ century. Nor can it be ruled out, even if the dimensions are to small to refer to a true "Roman camp" whose classical proportions are more like ten times larger (Hanson and Jones 2020; Hanson, Jones and Jones 2019; Reddé 2008). This type of ditch platform may just as well be from the medieval or modern period and correspond to settlement sites, such as fortified house enclosures (Margetts 2017) or game parks (Crozet, Laplaige and Rodier 2017; Zadora-Rio 1986).

\subsection{The motte-and-bailey castle? an elliptic moated site}

Another site is mentioned in the Répertoire Archéologique du Tarn-et-Garonne from Devals (1873) where he quotes, for the commune of Montech (p. 303): "In the forest of Montech, near the barraque of Carillon, a small primitive oppidum of elliptical shape, whose platform, raised 1.60 meters above the ground, measures 24 meters in its major axis, and 18 meters in its minor axis. The embankments are surrounded at their base by a 2-meter ditch". Again, there is no evidence of further investigation, so no general plan of the site was known beforehand and no dating evidence was collected on site.

A ten-minute LiDaR flyover allowed us to make a micro-topographical survey of this structure and to put it into context (Figure 9, Figure 10).

Again, this is a ditched platform, but it is elliptical in shape and much less extensive than the "Roman camp". The structures are relatively well preserved, as if fossilized by the absence of any forestry intervention in its extent (Figure 11). The platform measures $30 \mathrm{~m}$ on its long axis and $23 \mathrm{~m}$ on its short axis. It has an overhang of about one meter above the surrounding ground level and two meters above the bottom of the ditches. The ditches are 3 to $5 \mathrm{~m}$ wide and currently 50 to $70 \mathrm{~cm}$ deep. They have maintained a draining function and are sometimes partially filled with water.

The morphology of the structure allows the hypothesis of a medieval dating (a motte-and-bailey castle?) which is partially confirmed by a punctual collection of ceramic material carried out in 2016 on the top of the structure and in the bottom of a ditch. However, here again, the dimensions are modest, although not incompatible with the hypothesis of a motte-and-bailey. Several examples of this size have been archaeologically explored in France since the 1970s (Colardelle et al. 1979; De Bouard 1981; Noyé 1976) or recently excavated (Chevassu and Bichet 2019; Marchaisseau et al. 2010; Morel-Lecornué 2017) and elsewhere in Europe (Kiarszys 2017; Meyer, Pfeffer and Jürgens 2019). But this type of mound can also correspond to forest game management structures, such as rabbit warrens (Duceppe-Lamarre 1999; Zadora-Rio 1986, 2014).

In addition, this LiDaR survey reveals a whole network of ditches draining this space and leading in part to the mound ditches. These remains are absolutely invisible to the naked eye or in conventional aerial photography. 


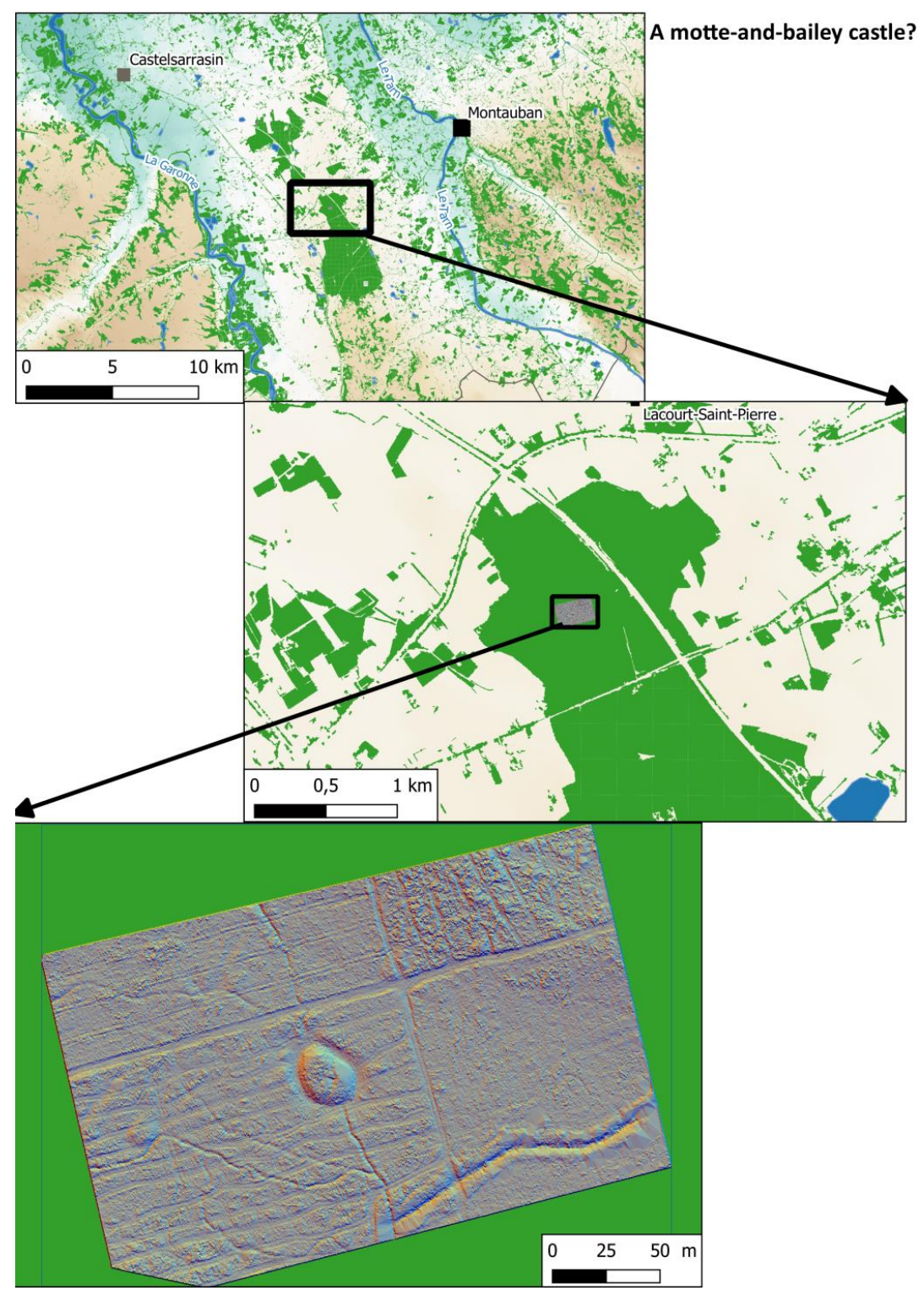

Figure 9. LiDaR survey of the Montech supposed motte-and-bailey and its micro-topographic context
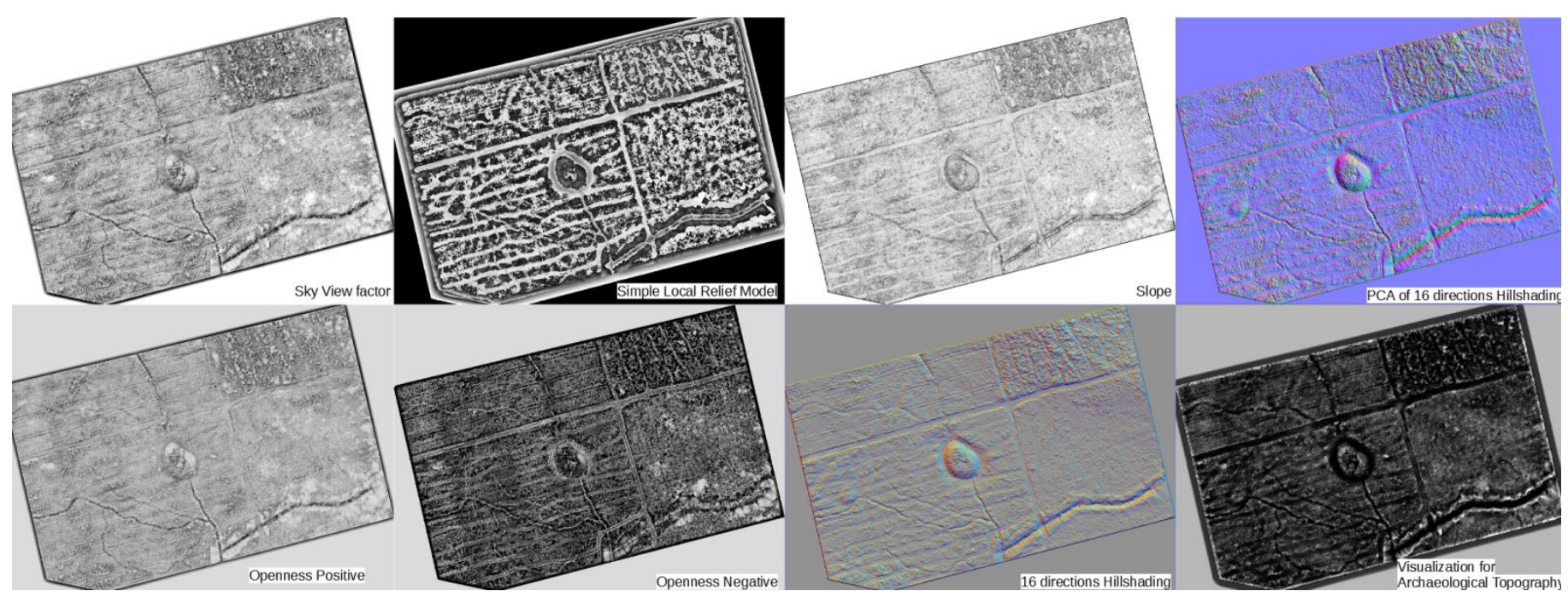

Figure 10. Different visualizations of the supposed motte-and-bailey 


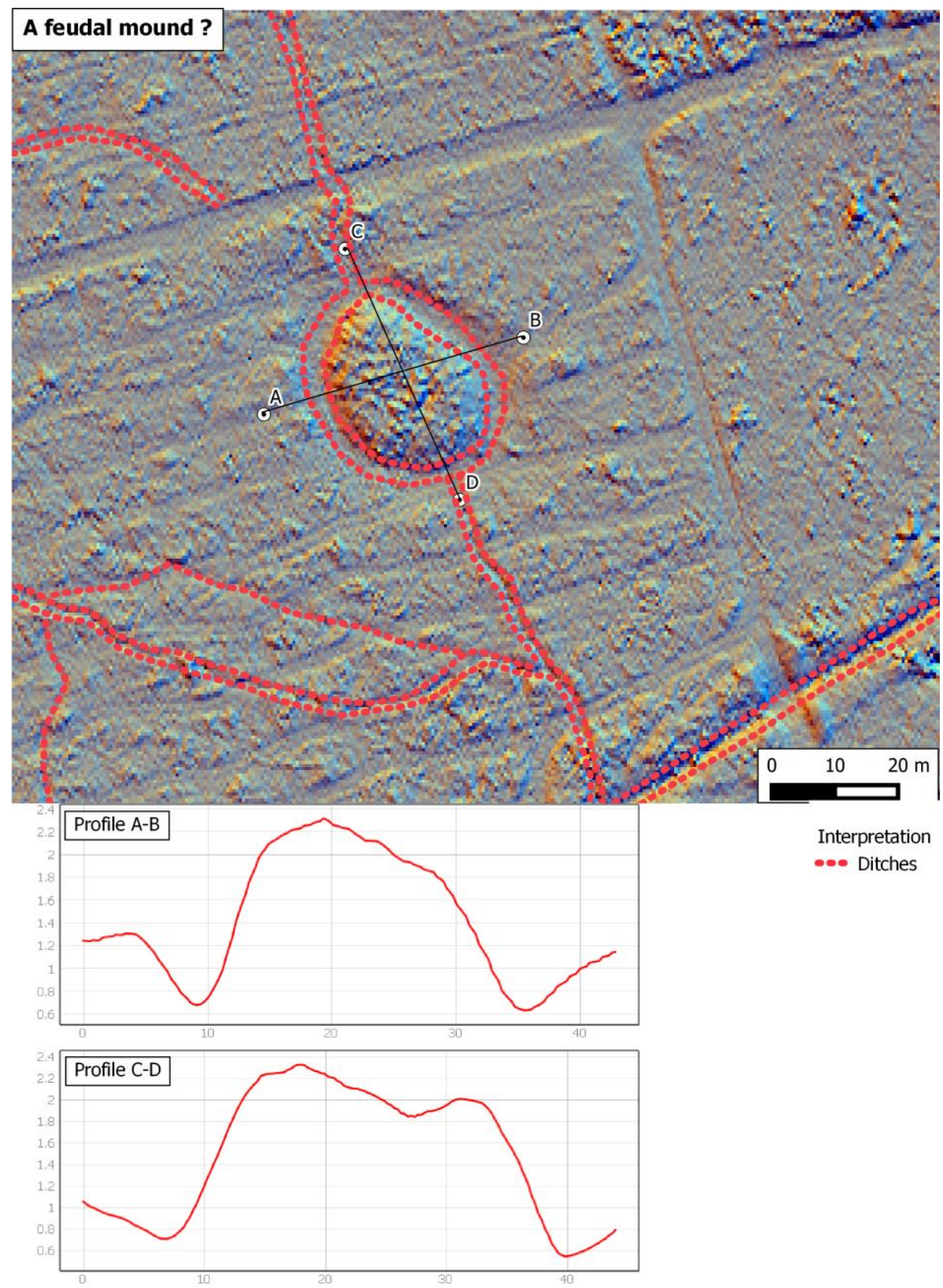

Figure 11. Interpretation of the remains of the presumed motte-and-bailey castle

\subsection{The medieval church? an isolated mound}

The church of Ganzelles, mentioned in the list of churches in Act 1 of the Cartulaire de SaintSernin de Toulouse (c. 1100) under the term Gavancelas, is shown on maps of the forest of 1607 (Astoul 2009). Located at a crossroads that can be seen on another map of 1666 (Figure 12), it had a statue of the Holy Virgin which gave rise to a pilgrimage. Every year people went there to celebrate Notre Dame, but also to eat, drink or dance (Langevin 1970). A wooden cross, known as the "Croix de Gancelles" or "Gauxelles", nowadays recalls its presence (Figure 13), although it seems to have been completely destroyed before the beginning of the $19^{\text {th }}$ century, since the Napoleonic cadastre does not mention it. 


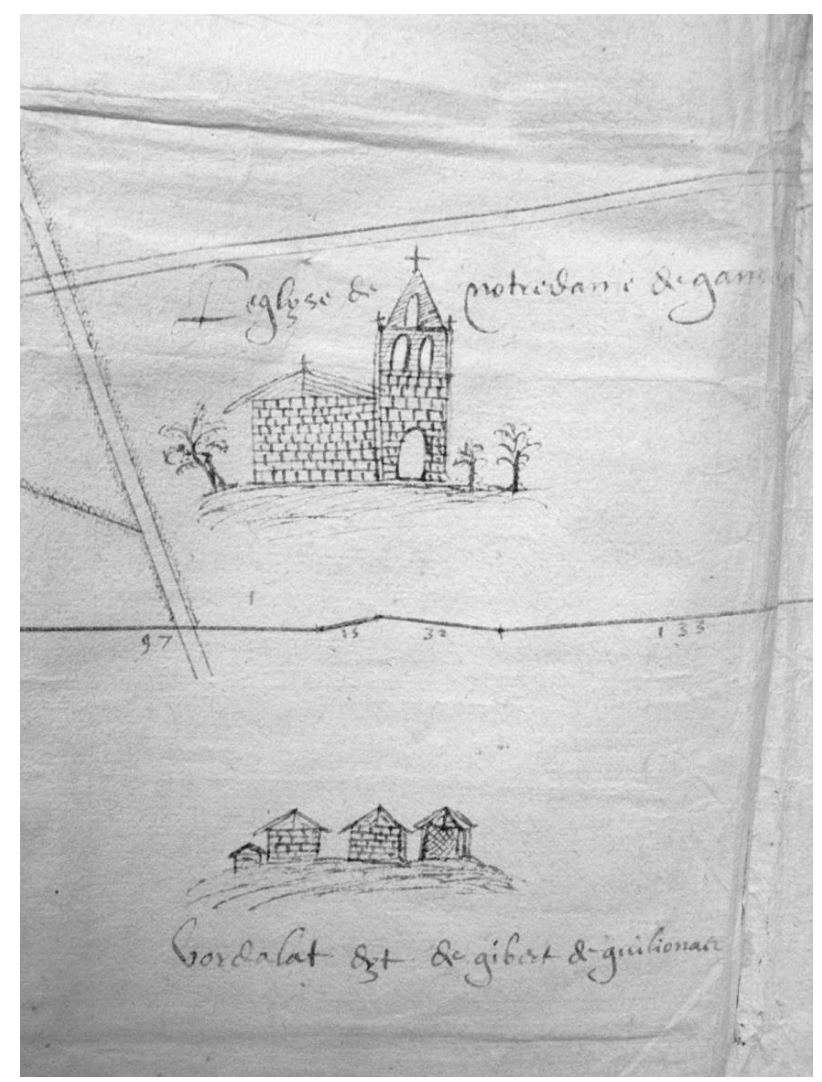

Figure 12. The church of Gavancelle in 1666

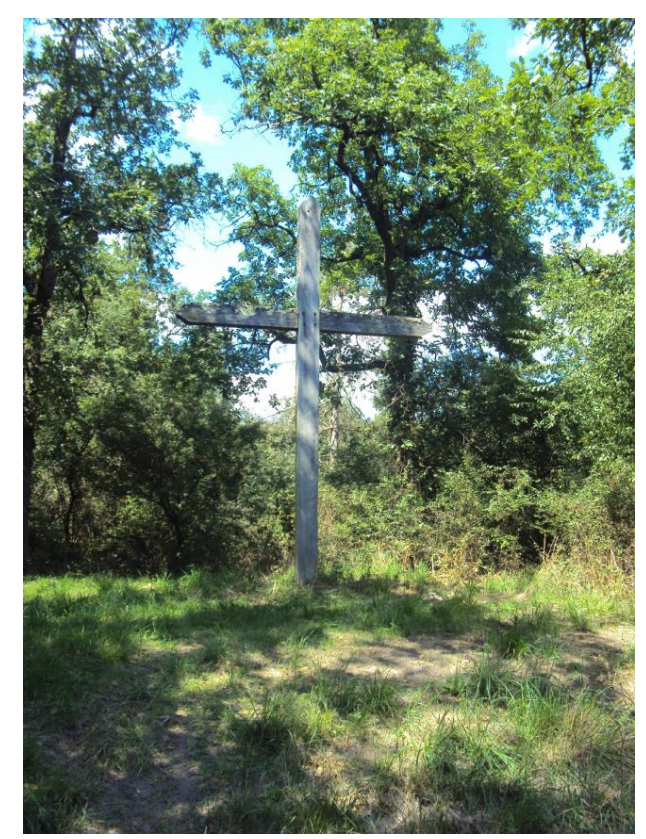

Figure 13. A cross now marks the location of the church.

LiDaR overflight of this area allows us to document a topographical anomaly that indicates the presence of the church (Figure 14). Located in the centre of the present-day Montech forest, on the edge of a forest road, a rectangular macro-relief can be seen. The dimensions of the mound are approximately $3 \mathrm{~m}$ long and $20 \mathrm{~m}$ wide (Figure 15). Section AB clearly distinguishes the remains of the two drip walls of the nave. They appear to be preserved over a height of about $1 \mathrm{~m}$; the interior of the structure appears to be partly filled in by the walls' collapse (Figure 16).

However, unlike the landscape restitution made possible by LiDaR at other sites (Gabellone et al. 2017; Masini et al. 2018), this survey does not reveal any other remains in the immediate vicinity of 
this church. No topographical anomalies can be identified and interpreted as remains of settlement, road network or agrarian development.

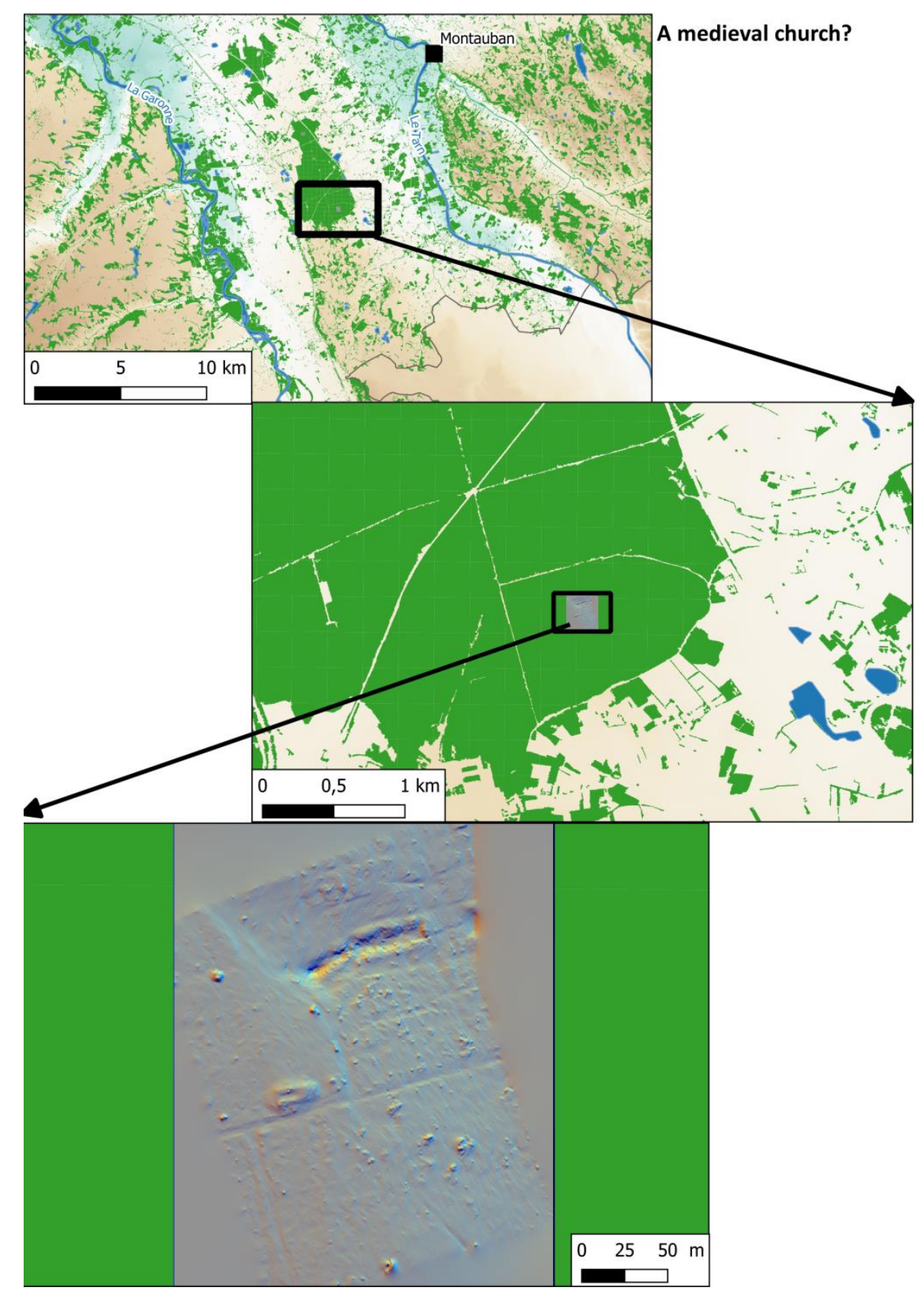

Figure 14. LiDaR survey of the Croix de Gancelles area 

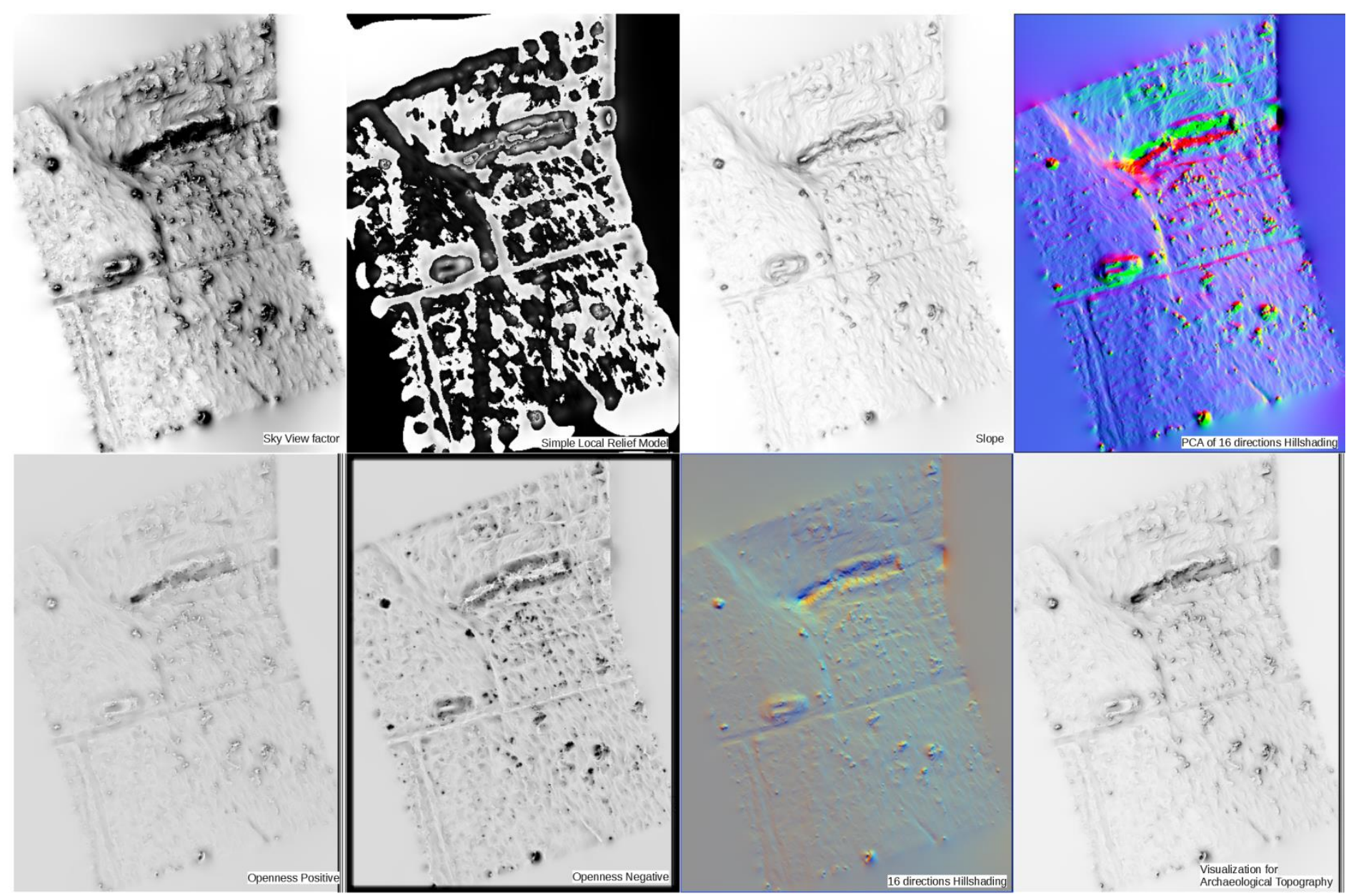

Figure 15. Different visualisations of the Gavancelle church site

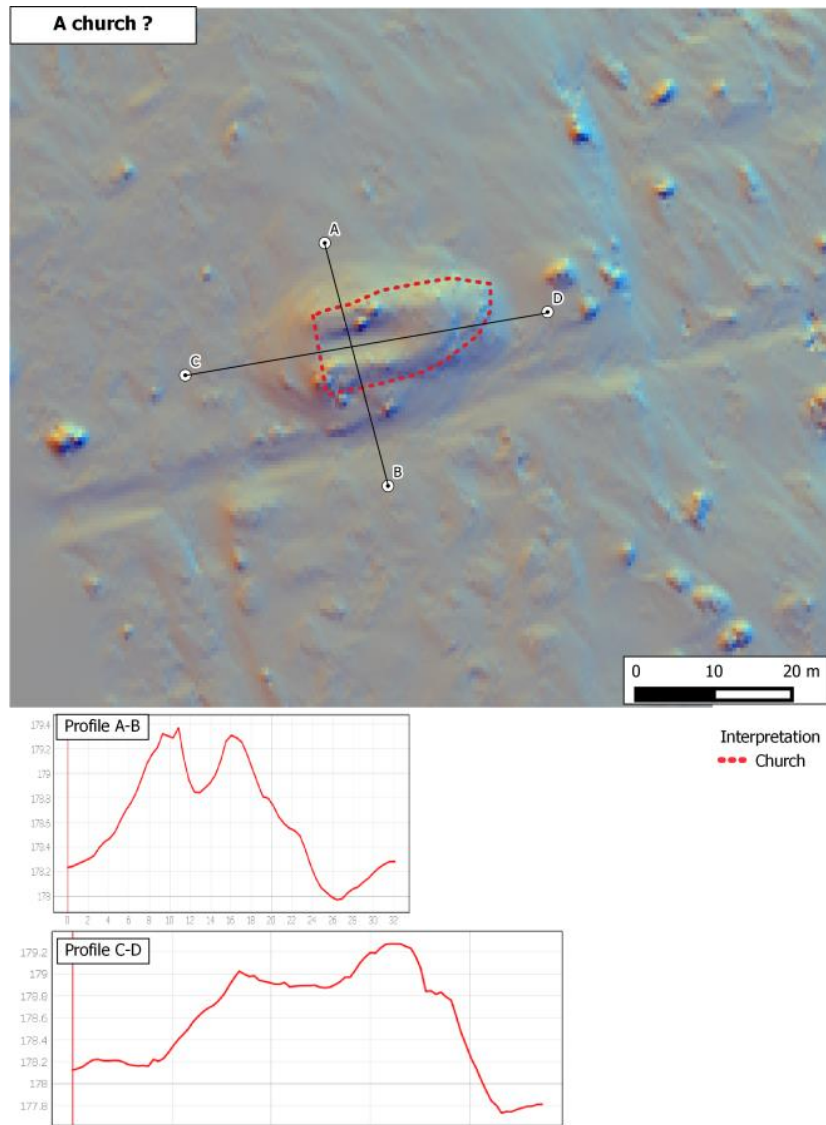

Figure 16. Interpretation of the remains of the church of Gavancelle 


\section{UAV vs plane: more quantity, less quality?}

\subsection{Increase of density \& decrease of spacing}

LiDaR UAV coverage of these three sites in the Agre forest were done in March 2017. In February 2020, a conventional LiDaR coverage by plane was carried out on this forested area. Without presenting these last data in detail, it is possible to compare the quality of the information obtained by a miniature LiDaR onboard a UAV compared to a conventional LiDaR, in the extent of an identical scene. We are mainly interested in three parameters concerning the ground points obtained according to identical procedures for both datasets (aircraft and UAV): the density of the ground points, their spacing, and their distribution in the scene.

To measure these three parameters, we used data acquired at the site of the supposed "Roman camp". It was covered twice by UAV (UAV1 on 17/03/2017; UAV2 on 05/04/2017) and once by aircraft (on 05/02/2020). To take advantage of the repeatability of UAV use, thus increase density and improve the distribution of ground points, we have also combined the points from the two UAV covers (UAV merge).

We've cut the drone and aircraft data sets to an identical extent. Then, ground points were extracted from its point clouds using the CSF module of the CloudCompare software with similar parameters: Cloth resolution $0.3-1000$ iterations - Classification threshold 0.2.

The average density and spacing values were calculated using the LasInfo tool from the LasTools suite and compiled in a spreadsheet.

It can be seen that a LiDaR coverage by UAV at a height of $50 \mathrm{~m}$ and a speed of $4 \mathrm{~m} / \mathrm{s}$ gives a density of ground points 3.7 times higher than a conventional LiDaR carried out by aircraft (between 59 and $68 \mathrm{pts} / \mathrm{m}^{2}$ on average with UAV against $17 \mathrm{pts} / \mathrm{m}^{2}$ with aircraft) (Figure 17). The average spacing of these ground points is also 2 times less $(0.13 \mathrm{~m}$ per UAV as opposed to 0.25 per aircraft) (Tableau 1).

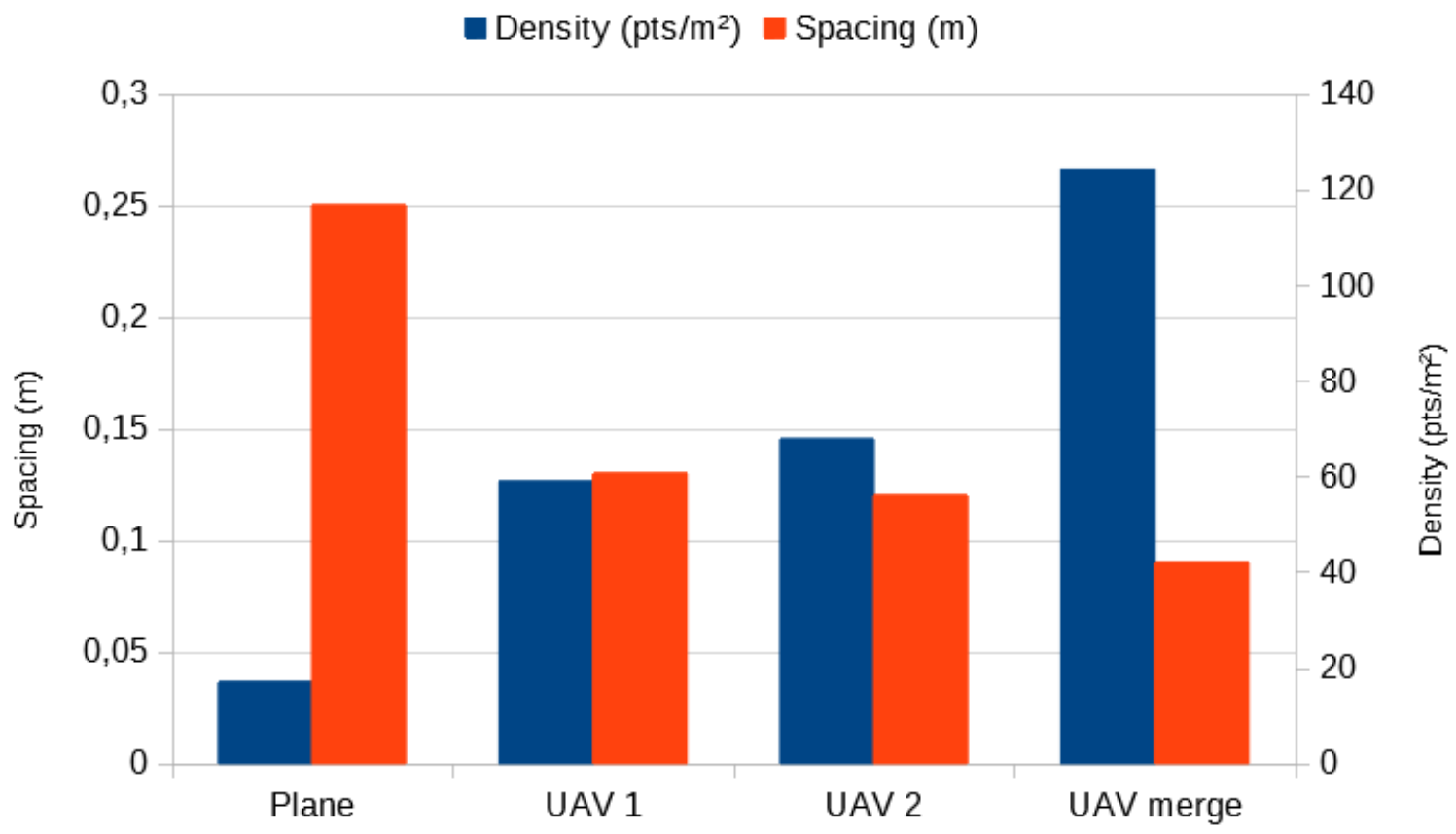

Figure 17. Comparison of UAV vs. aircraft point densities ("Roman camp" site) 


\begin{tabular}{|c|c|c|c|c|}
\hline "Roman Camp" (18202 m²) & Plane & UAV 1 & UAV 2 & UAV merge \\
\hline Total number of points & 785889 & 3433321 & 4459596 & 7892917 \\
\hline Total points density $\left(\mathrm{N} / \mathrm{m}^{2}\right)$ & 43 & 186 & 241 & 434 \\
\hline $\begin{array}{l}\text { Average spacing of total points } \\
\text { (m) }\end{array}$ & 0,15 & 0,07 & 0,06 & 0,06 \\
\hline Number of ground points & 303043 & 1075501 & 1234366 & 2309867 \\
\hline $\begin{array}{l}\text { Ground points / Total points } \\
\text { (\%) }\end{array}$ & $38,56 \%$ & 31,33 \% & $27,68 \%$ & $29,27 \%$ \\
\hline $\begin{array}{l}\text { Average density of ground } \\
\text { points }\left(\mathrm{N} / \mathrm{m}^{2}\right)\end{array}$ & 17 & 59 & 68 & 124 \\
\hline $\begin{array}{l}\text { Average spacing of ground } \\
\text { points }(\mathrm{m})\end{array}$ & 0,25 & 0,13 & 0,12 & 0,09 \\
\hline
\end{tabular}

Tableau 2. Comparison of UAV vs. aircraft LiDaR datasets ("Roman camp" site)

\subsection{Improvement of the spatial distribution}

We can add to this the possibility offered by the UAV to multiply overflights and data acquisitions on the same site, allowing to increase the density of the ground points and progressively fill in the white areas (Figure 18). Thus, the combination of ground points resulting from 2 overflights on the same site makes it possible to obtain a density more than 7 times higher than a single acquisition by aircraft $\left(124 \mathrm{pts} / \mathrm{m}^{2}\right)$ and an average spacing of $9 \mathrm{~cm}$.

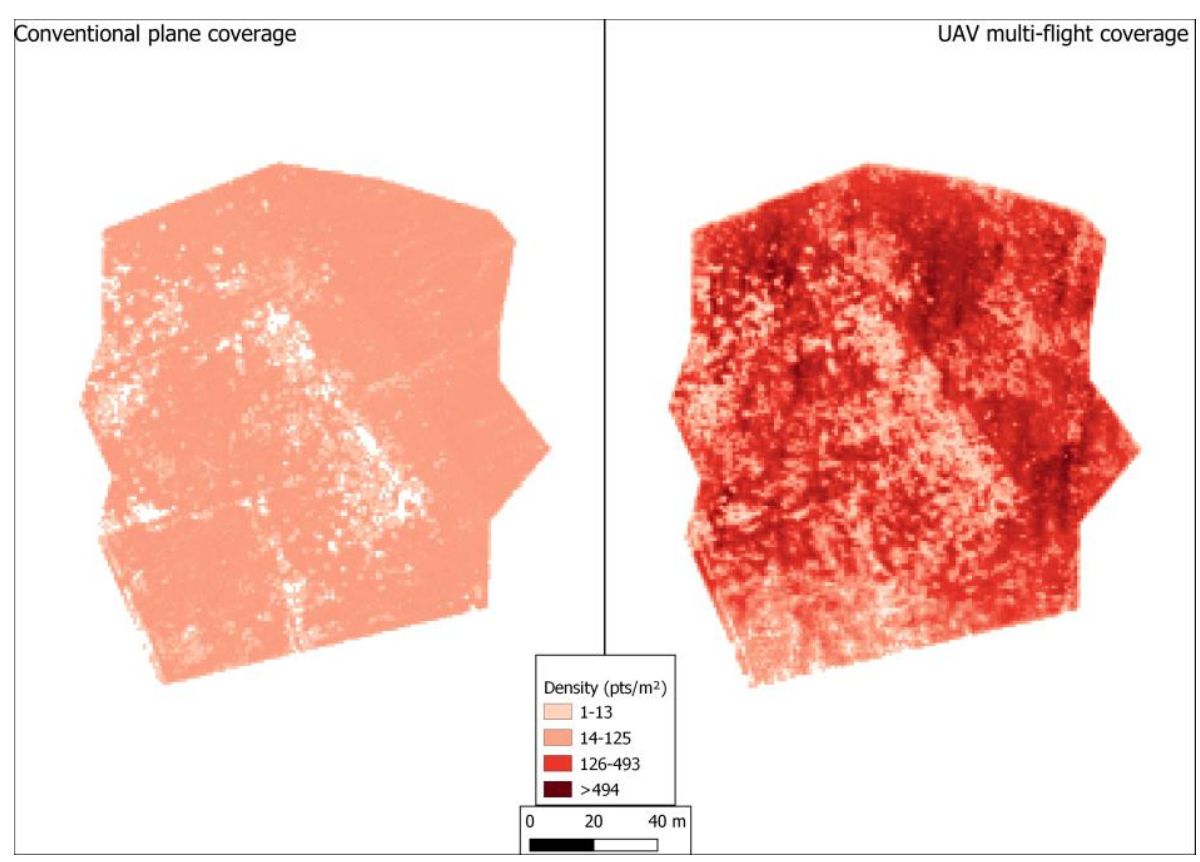

Figure 18. Density and distribution of ground points for data acquisition by UAV (left) and aircraft (right) 


\subsection{Quality of the data to be improved}

\subsubsection{Regularity \& alignment of flight tracks}

Despite the quality of the GPS positioning equipment of the UAV and the LiDaR sensor, as well as the performance of the post-processing software that improves the absolute positioning of the point cloud, the previous figure clearly shows the problems of regularity and homogeneity of threedimensional data acquisition by UAV.

Indeed, it is not uncommon for meteorological hazards, essentially linked to the strength and regularity of the wind, to disrupt the smooth running of a flight plan that has been meticulously prepared. This results in local variations in the speed and altitude of the UAV, naturally resulting in strong variations in the spatial distribution of point densities.

From this point of view, improvements are undoubtedly possible in the fusion of flight lines (optimizing assembly and overlapping), but also in the regular sampling of the most relevant points.

Another way of improvement would be to use a GPS base station in the field of data acquisition instead of using data from the base stations of the Permanent Geodetic Network of the French National Geographic Institute for differential post-processing of GPS data. It would also be possible to develop a procedure involving the placement and use of ground targets to improve the alignment and fusion of flight lines.

However, these avenues for improvement would create logistical and organisational difficulties that today seem to outweigh the benefits that could be derived from them. The choice is more about exploiting the flexibility of use allowed by the UAV, which would be greatly reduced by the constraints of complementary topographical field work.

\subsubsection{Point cloud thickness and noise}

An important criterion for estimating the quality of the acquired three-dimensional data is to measure the "thickness" of the layer of points supposed to materialize the bare ground surface, after filtering the vegetation. Indeed, from a theoretical point of view, this thickness should be zero and the interface between the soil and the subsoil represented by a uniform layer of points. However, this is rarely the case, even if one considers very homogeneous surfaces such as masonry or concrete floors. Irrespective of the absolute positioning of the points in space, this is due to the accuracy of the sensor itself. The emission and reception qualities of the $\mathrm{LiDaR}$ echoes by the numerous available sensors are variable, and can be impaired by too large scanning angles at the edge of the swath, for example. Our ground point sampling procedures therefore include a filtering step for scanning angles greater than $30^{\circ}$ around the Nadir. In spite of this pre-selection, the thickness of the layer of points representing the ground is never zero, particularly in forested environments and after a procedure of classification and filtering of the ground points only. Its amplitude makes it possible to estimate the amount of "noise" altering the topographic information sought. This is an important information for an archaeological application of LiDaR, since it determines the size of the archaeological micro-reliefs that can be detected.

The procedure used here to estimate this information consists, under the CloudCompare software, in extracting from the ground point layer of each data acquisition (UAV and aircraft) several areas of the scene, as flat as possible, by varying their size. A regression plane is then calculated for each test area (via the "Fit>Plane" tool), then the Euclidean distance between each point of the test area and this newly created reference surface is measured. The average of the absolute values of its Euclidean distances is then calculated and multiplied by two to estimate the average thickness of the 
point cloud. Indeed, the average of the distances above (D1) is close to the value of the distances below (D2) since the regression plane distributes the points at best (Figure 19).

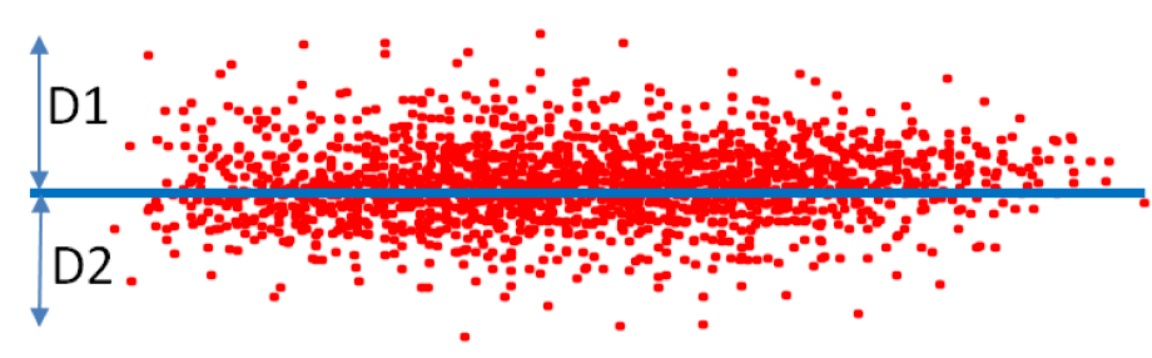

Figure 19. Distribution of points above and below the regression plan. Points cloud thickness (or noise) is estimated by $D 1+D 2$.

Using the site of the "Roman Camp" and its different coverage by drone and aircraft as an example, this procedure was used on three test areas that were as flat as possible, of different sizes, two located under forest $-5 \mathrm{~m}$ sides for one, $10 \mathrm{~m}$ for the other - and the last on a supposedly homogeneous and regular surface, namely a $3 \mathrm{~m}$ section of asphalt road. Despite the variations in the size of the test areas and the size of the point clouds concerned (between UAV and aircraft), the results, which are very close, tend to demonstrate a certain robustness of the following observations.

It emerges that the information obtained from a traditional LiDaR coverage operated by aircraft is always of better quality than that obtained by a miniaturised LiDaR sensor onboard a UAV, with point cloud thicknesses of 6.7 to $7.8 \mathrm{~cm}$, compared to 11.7 to $12.2 \mathrm{~cm}$ for the LiDaR UAV (Tableau 2 ). The development of future miniaturised sensors with better performance should make it possible to reduce this noise, as well as the reduction of the intervals between the lines of flight to favour a more rigorous selection of the safest points (better scanning angle for example).

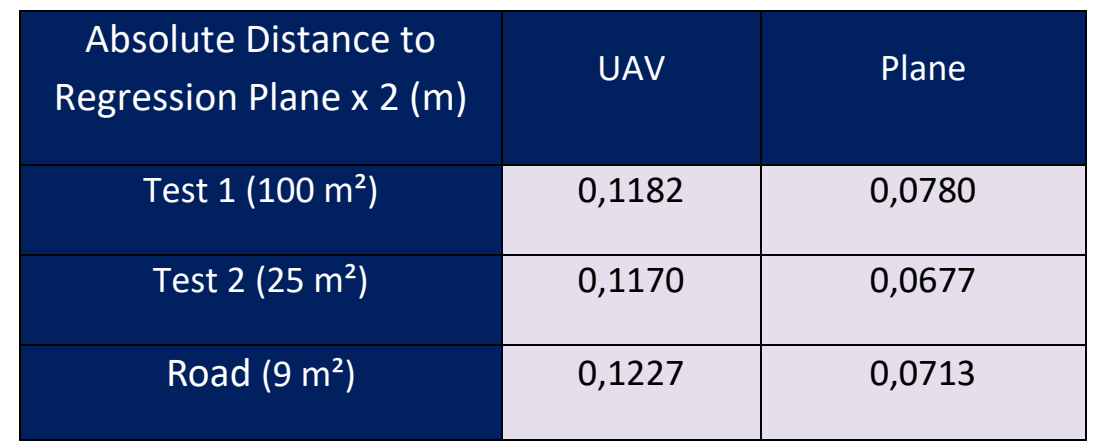

Tableau 2. Estimation of point cloud thickness by test area

\section{Conclusion}

This study demonstrates the usefulness of having miniaturized LiDaR sensors onboard drones to help document archaeological sites and structures preserved under the current forest canopy.

Of course, the coverage of large wooded areas, larger than a hundred hectares, must remain the prerogative of conventional LiDaR carried by plane or helicopter. But miniature LiDaR onboard UAV has an important role to play in a) documenting known but isolated archaeological sites in the heart of forest areas not covered by conventional LiDaR and for which the acquisition of 
topographical information is necessary, and b) to introduce small forested areas - and the archaeological traces they contain - in studies of land use history.

Concerning the first point, it is important to be able to map archaeological structures that may have been identified in the field, but never recorded in detail by making plans, sections, and other surveys useful for their description. The recording of this information is not only necessary to establish the state of archaeological knowledge of a given area, but can also be decisive in the heritage preservation of these sites, which are not necessarily included in wooded areas covered by conventional LiDaR. LiDaR onboard drone is therefore a useful instrument for the diagnosis of the conservation state of these remains, but also, thanks to the flexibility of use that is allowed, an instrument for the periodic control of the possible degradation of these structures, simply due to natural erosion, but which can also be aggravated by logging operations (cutting, skidding). This periodic monitoring would also be useful in the event of a threat to the integrity of the remains by development or exploitation projects, such as quarries for example.

Concerning the second point, the small range of action of UAVs (a few tens of hectares per day) also corresponds to the useful scale for the documentation of small forest plots that can be disconnected from each other. Those are generally not the subject of large data acquisition operations in conventional LiDaR, given that the price increases drastically when the area decreases, mainly due to the fixed costs related to the use of an aerial vector (plane or helicopter). This probably results in a current under-evaluation of the archaeological potential of these small woodlands, which often constitute "holes" in archaeological maps, due to the difficulties of surveying in a wooded environment. A more systematic diagnosis and monitoring of these small wooded areas would therefore make it possible to reconstruct the dynamics of land use in the continuity of the geographical space required for this type of study.

\section{References}

Agudo, P U, Pajas, J A, Pérez-Cabello, F, Redón, J V and Lebrón, B E 2018 The Potential of Drones and Sensors to Enhance Detection of Archaeological Cropmarks: A Comparative Study Between Multi-Spectral and Thermal Imagery, Drones, 2(3): 29. DOI: https://doi.org/10.3390/drones2030029.

Astoul, G 2009 La forêt de Montech et ses représentations au XVIIe siècle, Bulletin de la Société Archéologique et Historique du Tarn-et-Garonne, 134.

Bennett, R, Welham, K, Hill, R A and Ford, A 2012 A Comparison of Visualization Techniques for Models Created from Airborne Laser Scanned Data, Archaeological Prospection, DOI: https://doi.org/10.1002/arp.1414.

Bewley, R H, Crutchley, S P and Shell, C A 2005 New light on an ancient landscape: lidar survey in the Stonehenge World Heritage Site, Antiquity, 79(305): 636-647. DOI: https://doi.org/10.1017/S0003598X00114577.

Campana, S 2017 Drones in Archaeology. State-of-the-art and Future Perspectives, Archaeological Prospection, n/an/a. DOI: https://doi.org/10.1002/arp.1569.

Challis, K, Kokalj, Z, Kincey, M, Moscrop, D and Howard, A J 2008 Airborne lidar and historic environment records, Antiquity, 82(318): 1055-1064. DOI: https://doi.org/10.1017/S0003598X00097775.

Chevassu, V and Bichet, V 2019 Fourgs (Les) (Doubs). Plateau des Fourgs ?, Archéologie médiévale, (49): 371.

Colardelle, M, Mazard, C, Bailly-Maître, M-C, Bois, M, Dupraz, J, Carbonnières, P de and Sirot, É 1979 Premiers résultats des recherches sur les «mottes » médiévales en Dauphiné et en Savoie, Archéologie médiévale, 9(1): 6595. DOI: https://doi.org/10/ggzgmq.

Crozet, A, Laplaige, C and Rodier, X 2017 Une approche multidisciplinaire de la fabrique des paysages dans la longue durée dans les forêts de Blois, Russy, Boulogne et Chambord (Loir-et-Cher), Projets de paysage: revue scientifique sur la conception et l'aménagement de l'espace,.

De Bouard, M 1981 Les fortifications de terre en Europe occidentale du 10e au 12e siècle, colloque de Caen, 2-5 octobre 1980, Thème 1, La motte, Archéologie Médiévale, 11: 6-33. 
Deffontaines, P 2000 Les hommes et leurs travaux dans les pays de la moyenne Garonne (Agenais, Bas Quercy). Agen: Libr. Quesseveur.

Delsouc, M 2001 Le paysage dans la gestion de la fôret domaniale d'Agre en Tarn et Garonne. PhD Thesis.

Devereux, B J, Amable, G S, Crow, P and Cliff, A D 2005 The potential of airborne lidar for detection of archaeological features under woodland canopies, Antiquity, 79(305): 648-660. DOI: https://doi.org/10.1017/S0003598X00114589.

Doyen, B, Decocq, G and Thuillier, P 2004 Archéologie des milieux boisés en Picardie, Revue archéologique de Picardie, 1(1): 149-164. DOI: https://doi.org/10/bzgrpd.

Duceppe-Lamarre, F 1999 L'archéologie du paysage à la conquête des milieux forestiers, ou l'objet paysage vu par l'archéologue de l'environnement, Hypotheses, 2(1): 85-94. DOI: https://doi.org/10/ggx9sh.

Dupin, A, Girardclos, O, Fruchart, C, Laplaige, C, NUNINGER, L, Dufraisse, A and Gauthier, E 2017 Anthracology of charcoal kilns in the forest of Chailluz (France) as a tool to understand Franche-Comte forestry from the mid15th to the early 20th century AD, Quaternary International, 458: 200-213. DOI: https://doi.org/10.1016/j.quaint.2017.03.008.

Gabellone, F, Lanorte, A, Masini, N and Lasaponara, R 2017 From remote sensing to a serious game: Digital reconstruction of an abandoned medieval village in Southern Italy, Journal of Cultural Heritage, 23: 63-70. DOI: https://doi.org/10/gf56vx.

Georges-Leroy, M, Bock, J, Dambrine, E and Dupouey, J-L 2010 Le massif forestier, objet pertinent pour la recherche archéologique. L'exemple du massif forestier de Haye (Meurthe-et-Moselle), Revue Géographique de l'Est, 49(23): .

Georges-Leroy, M, Bock, J, Dambrine, É and Dupouey, J-L 2011 Apport du lidar à la connaissance de l'histoire de l'occupation $\mathrm{du}$ sol en forêt de Haye, ArchéoSciences, (35): 117-129. DOI: https://doi.org/10.4000/archeosciences.3015.

Gilles, H 1966 L'administration royale des eaux et forêts en Languedoc au Moyen Âge. Bibliothèque nationale.

Glaves, P, Rotherham, I D, Wright, B, Handley, C and Birbeck, J 2009 Field Surveys for Ancient Woodlands: Issues and Approaches.

Hanson, W S and Jones, R E 2020 The Roman fort and fortlet at Castlehill on the Antonine Wall: the geophysical, LiDAR and early map evidence.

Hanson, W S, Jones, R E and Jones, R H 2019 The Roman Military Presence at Dalswinton, Dumfriesshire: a Reassessment of the Evidence from Aerial, Geophysical and LiDAR Survey, Britannia, 50: 285-320. DOI: https://doi.org/10/ggx8zb.

Hendrickx, M, Gheyle, W, Bonne, J, Bourgeois, J, De Wulf, A and Goossens, R 2011 The use of stereoscopic images taken from a microdrone for the documentation of heritage - An example from the Tuekta burial mounds in the Russian Altay, Journal of Archaeological Science, 38(11): 2968-2978. DOI: https://doi.org/10.1016/j.jas.2011.06.013.

Hesse, R 2010 LiDAR-derived Local Relief Models-a new tool for archaeological prospection, Archaeological Prospection, 17(2): 67-72.

Higounet, C 1975 Paysages et villages neufs du Moyen-Age. Bordeaux.

Humme, A, Lindenbergh, R and Sueur, C 2006 Revealing Celtic fields from lidar data using kriging based filtering. In: Proceedings of the ISPRS Commission V Symposium, Dresden. 2006 pp. 25-27.

Kiarszys, G 2017 Palimpsests of medieval landscapes. A case study from Lower Silesia Region, Poland, AARGnews, 54: 21-36.

Kokalj, Ž and Somrak, M 2019 Why Not a Single Image? Combining Visualizations to Facilitate Fieldwork and OnScreen Mapping, Remote Sensing, 11(7): 747. DOI: https://doi.org/10.3390/rs11070747.

Kokalj, Z, Zaksek, K and Ostir, K 2011 Application of Sky-View Factor for the Visualisation of Historic Landscape Features in Lidar-Derived Relief Models, Antiquity, 85(327): 263.

Langevin, M 1970 Histoire de la forêt de Montech, Bulletin de la Société Archéologique et Historique du Tarn-etGaronne, 96: 105-120.

Marchaisseau, V, Deborde, J, Pilliot, C and Turé, I 2010 La motte médiévale de Drosnay (Marne) : résultats de deux sondages archéologiques, Revue archéologique de l'Est, (Tome 59-2): 669-681. 
Margetts, A 2017 A medieval moated site and manorial complex rediscovered through LiDAR at Broadbridge Heath, West Sussex, Sussex Archaeological Collections, 155: 111-17.

Masini, N, Gizzi, F T, Biscione, M, Fundone, V, Sedile, M, Sileo, M, Pecci, A, Lacovara, B and Lasaponara, R 2018 Medieval Archaeology Under the Canopy with LiDAR. The (Re)Discovery of a Medieval Fortified Settlement in Southern Italy, Remote Sensing, 10(10): 1598. DOI: https://doi.org/10.3390/rs10101598.

Meng, X, Currit, N and Zhao, K 2010 Ground Filtering Algorithms for Airborne LiDAR Data: A Review of Critical Issues, Remote Sensing, 2(3): 833-860. DOI: https://doi.org/10.3390/rs2030833.

Meyer, M F, Pfeffer, I and Jürgens, C 2019 Automated Detection of Field Monuments in Digital Terrain Models of Westphalia Using OBIA, Geosciences, 9(3): 109. DOI: https://doi.org/10/gf57wh.

Morel-Lecornué, S 2017 Serrigny-en-Bresse (Saône-et-Loire). «La Motte », Archéologie médiévale, (47): 253.

Nelson, R F 1989 The Use Of Aircraft Laser Ranging Data For Forest Mensuration. In: Sokoloski, M.M. (ed.) SPIE Proceedings. 25 July 1989 pp. 155-163. DOI: https://doi.org/10.1117/12.951875.

Noël, M 1996 L'homme et la forêt en Languedoc-Roussillon. Perpignan: Presses Universitaires de Perpignan.

Noyé, G 1976 Les fortifications de terre dans la seigueurie de Toucy, du Xe au XIIIe siècle. Essai de typologie, Archéologie médiévale, 6(1): 149-217. DOI: https://doi.org/10/ggzgk9.

Poirier, N 2017 From Archaeological Evidence of Agrarian Manuring to the Understanding of Settlements and Landscape's Dynamics: an Experiment of Non-invasive Archaeological Methods in South-West France. In: Finds in the landscape - New perspectives and results from archaeological field surveys. 11 June 2017 Cologne. p.

Poirier, N, Hautefeuille, F and Calastrenc, C 2013 Low Altitude Thermal Survey by Means of an Automated Unmanned Aerial Vehicle for the Detection of Archaeological Buried Structures, Archaeological Prospection, 20(4): 303-307. DOI: https://doi.org/10.1002/arp.1454.

Py-Saragaglia, V, Cunill Artigas, R, Métailié, J-P, Ancel, B, Baron, S, Paradis-Grenouillet, S, Lerigoleur, É, Badache, N, Barcet, H and Galop, D 2017 Late Holocene history of woodland dynamics and wood use in an ancient mining area of the Pyrenees (Ariège, France), Quaternary International, 458: 141-157. DOI: https://doi.org/10.1016/j.quaint.2017.01.012.

Rackham, O 1980 Ancient woodland, its history, vegetation and uses in England., Ancient woodland, its history, vegetation and uses in England.,.

Rassat, G, Allée, P, Dieudonné-Glad, N and Bal-Serin, M-C 2013 Searching for and studying charcoal production platforms: the utilization and implementation of LiDAR technology in charcoal-based archaeological studies. Charbonnage, Charbonnier, Charbonnière / Wood charcoal production, charcoal burners, charcoal kilns, 12 September 2013. Available at https://hal-unilim.archives-ouvertes.fr/hal-01127139 [Last accessed 24 January 2020].

Reddé, M 2008 Les camps militaires républicains et agustéens: paradigmes et réalités archéologiques, Saldvie: Estudios de prehistoria y arqueología, (8): 61-72.

Risbøl, O and Gustavsen, L 2018 LiDAR from drones employed for mapping archaeology - Potential, benefits and challenges, Archaeological Prospection, 25(4): 329-338. DOI: https://doi.org/10.1002/arp.1712.

Roberts, N, Fyfe, R M, Woodbridge, J, Gaillard, M-J, Davis, B a. S, Kaplan, J O, Marquer, L, Mazier, F, Nielsen, A B, Sugita, S, Trondman, A-K and Leydet, M 2018 Europe's lost forests: a pollen-based synthesis for the last 11,000 years, Scientific Reports, 8(1): 716. DOI: https://doi.org/10/gcvw7d.

Rotherham, I D 2007 The implications of perceptions and cultural knowledge loss for the management of wooded landscapes: A UK case-study, Forest Ecology and Management, 249(1): 100-115. DOI: https://doi.org/10/cm842r.

Sittler, B 2004 Revealing historical landscapes by using airborne laser scanning. A 3-D model of ridge and furrow in forests near Rastatt (Germany), International Archives of Photogrammetry (ISPRS), 26: 258-261.

Štular, B, Oštir, K, Nuninger, L and Kokalj, Ž 2012 Visualization of lidar-derived relief models for detection of archaeological features, Journal of Archaeological Science, 39(11): 3354-3360. DOI: https://doi.org/10.1016/j.jas.2012.05.029.

Szabó, P, Müllerová, J, Suchánková, S and Kotačka, M 2015 Intensive woodland management in the Middle Ages: spatial modelling based on archival data, Journal of Historical Geography, 48: 1-10. DOI: https://doi.org/10.1016/j.jhg.2015.01.005. 
Viader, R and Rendu, C eds. 2014 Cultures temporaires et féodalité: Les rotations culturales et l'appropriation du sol dans l'Europe médiévale et moderne. Presses universitaires du Midi. DOI: https://doi.org/10.4000/books.pumi.9694.

Wehr, A and Lohr, U 1999 Airborne laser scanning-an introduction and overview, ISPRS Journal of Photogrammetry and Remote Sensing, 54(2-3): 68-82. DOI: https://doi.org/10.1016/S0924-2716(99)00011-8.

Zadora-Rio, E 1986 Parcs à gibier et garennes à lapins : contribution à une étude archéologique des territoires de chasse dans le paysage médiéval, Hommes et Terres du Nord, 2(1): 133-139. DOI: https://doi.org/10.3406/htn.1986.2054.

Zadora-Rio, E 2014 Les fortifications de terre médiévales et leurs avatars : perspective historiographique. In: ZadoraRio, E. (ed.) Atlas Archéologique de Touraine. Supplément à la Revue Archéologique du Centre de la France. Tours: FERACF. p.

Zakšek, K, Oštir, K and Kokalj, Ž 2011 Sky-View Factor as a Relief Visualization Technique, Remote Sensing, 3(2): 398-415. DOI: https://doi.org/10/ffxndc.

Zhang, W, Qi, J, Wan, P, Wang, H, Xie, D, Wang, X and Yan, G 2016 An Easy-to-Use Airborne LiDAR Data Filtering Method Based on Cloth Simulation, Remote Sensing, 8(6): 501. DOI: https://doi.org/10.3390/rs8060501. 